\title{
Toxic Effects of Purified Microcystins from Soil Blue-Green Alga Oscillatoria pseudogeminata on Tomato Plant Lycopersicon esculentum
}

\author{
Emad yousif Awad Al-Sultan*
}

Mustafa Taher Hatem

Received 6/5/2018, Accepted 2/9/2018, Published 17/3/2019

This work is licensed under a Creative Commons Attribution 4.0 International License.

\begin{abstract}
:
The current study included the isolation, purification and cultivation of blue-green alga Oscillatoria pseudogeminata G.Schmidle from soil using the BG-11liquid culture medium for 60 days of cultivation. The growth constant $(\mathrm{k})$ and generation time $(\mathrm{G})$ were measured which $(\mathrm{K}=0.144)$ and $(\mathrm{G}=2.09$ days).

Microcystins were purified and determined qualitatively and quantitatively from this alga by using the technique of enzyme linked immunosorbent assay (Elisa Kits). The alga showed the ability to produce microcystins in concentration reached $1.47 \mu \mathrm{g} / \mathrm{L}$ for each $50 \mathrm{mg}$ DW. Tomato plants (Lycopersicon esculentum) aged two months were irrigated with three concentrations of purified microcystins $0.5,3.0$ and $6.0 \mu \mathrm{g} / \mathrm{L}$ for 24 days. The results showed that the highest bioaccumulation of these toxins was found in the plant group treated with concentration $6.0 \mu \mathrm{g} / \mathrm{L}$, with an average of $12.278 \mu \mathrm{g} / \mathrm{L}$ in the entire plant body, with a daily accumulation rate of $0.511 \mu \mathrm{g} /$ day compared with control group and other treatments $(\mathrm{p} \leq 0.05)$.

The highly accumulation of toxin was found in roots followed in descending order by stems and leaves respectively and were directly proportional to the increased concentration of purified microcystins. The study indicated that there were significant changes $(\mathrm{p} \leq 0.05)$ in the plant height, length of roots and surface area of the leaves and the leaves appeared pale green in color, which increased with increasing the concentration of purified toxin. The obtained results also showed a significant decrease in the concentration of carbohydrates and chlorophylls by increasing concentrations of purified toxins.
\end{abstract}

Key words: Lycopersicon esculentum, Microcystins toxins, Oscillatoria pseudogeminata, Tomato plant.

\section{Introduction:}

Cyanobacteria (blue-green algae) found in different habitats including fresh, brackish, marine water and soil (1). Several genera belonging to cyanobacteria as Microcystis, Anabaena, Oscillatoria, Haapalosiphon, Radiocystis, Stigonema, Lyngbya, Pseudoanabaena and Phormidium are known to produce microcystins (Hepatotoxins) and neurotoxins or both. (2, 3, 4). Many species of blue green algae reach approximately to 80 species can produce hepatotoxin (Microcystins only) (5). The safe levels of microcystins are approximately $0.3 \mu \mathrm{g} / \mathrm{L}$ in drinking water for children, while for other ages reach to $1.6 \mu \mathrm{g} / \mathrm{L}$ (6), but the concentration of these toxins may reach to $100 \mu \mathrm{g} / \mathrm{L}$ in some water bodies (7). The proliferation of toxic and non-toxic bluegreen algae in aquatic habitats is well known as a famous phenomenon. However, the expansions of toxic species to a wide range may cause harmful effects on ecosystems (8).

Department of Biology, College of Education for Pure Sciences, Basra University, Basra, Iraq

"Corresponding author: emad_yousif2000@yahoo.com
Water blooms of blue-green algae have caused many damages to environment conditions and human health in recent decades and impediment to biological waste water treatment $(9,10)$. Microcystins are secondary metabolites produced by blue-green algae and causes toxicity to higher organisms including humans, plants as well as food supplements $(11,12)$, the effect of blue green algae and their toxins in agriculture is not yet understood especially microcystins-LR (13). On the other hand, the water used for irrigation often comes from natural water systems or ponds constructed for agricultural purposes which are not subject to the examination and treatment or monitoring of microcystins. In addition, the cyclic composition of these toxins provides a high chemical stability with its ability to stay in the soil for a long time. Recently, the half-life of these toxins in agricultural soil is estimated as 56 days (14). Consequently, the presence of these toxins in both irrigation and soil water can have a negative impact on soil organisms as well as on the growth and development of crop plants (7). The cyanotoxins in the soil may be transported to water bodies again by runoff 
,leaching process or accumulation in soil ,consequently, this cause contamination of plants especially leaves and fruits (15). The current study is devoted to determining the toxic effects of hepatotoxins (Microcystins) which was isolated and purified from soil blue-green alga Oscillatoria pseudogeminata with very low concentrations less than the permitted concentrations worldwide, as well as higher concentrations on one of the economically important tomato plants (Lycopersicon esculentum).

\section{Materials and Methods:}

\section{Sample collection of soil blue-green alga}

Wet soil samples containing developing algae were collected in the area of the Dafas orchards located adjacent to the Tigris River in the district of Maysan governorate. Clean sealed plastic containers were used to collect the soil samples. Samples were collected at a depth of $3 \mathrm{~cm}$ from the soil surface, and then were brought directly to the laboratory to isolate and cultivate the algal species.

\section{Isolation of blue-green algae from soil samples}

$1 \mathrm{~g}$ of wet soil sample was taken and mixed with $10 \mathrm{ml}$ distill water and put in a test tube and then inserted into the Centrifuge type ( TLEDanger) quickly $3000 \mathrm{rpm}$ for $10 \mathrm{~min}$. After that the algae were scrapped from the surface of the precipitate and increased by $10 \mathrm{~mL}$ of distilled water. Several drops were taken for making glass slides from each sample to identify their algal content by using the Olympus CX21 optical microscope. (Under the magnification X4, X10, $\mathrm{X} 40$ and $\mathrm{X} 100$ ). Then $5 \mathrm{ml}$ of algal solution was taken and washed several times with distill water using centrifugation at $3000 \mathrm{rpm}$ and $10 \mathrm{~min}$ that in order to get rid of soil, plankton and impurities, then $1 \mathrm{ml}$ of washed samples were put in a test tube and completed to $5 \mathrm{ml}$ by sterile liquid media and left in the incubator for 7-10 days. After the algae growth on the walls of test tubes was obtained, the dilution method was made to get unialgal cultures (16).

\section{Purification of unialgal cultures of blue-green alga}

After obtaining algal culture of alga $O$. pseudogeminata, Weidman et al., (17) method was used to obtain the axenic culture according to the following. Unialgal cultures were washed with sterile distilled water and then centrifuged at 3000 rpm for 5 minutes, leave the leachate and recombine the precipitate with distill water again and repeat this process 10 times. To ensure the purity of the isolates, the method described by stein (16), which included the cultivation of algal isolate in nutrient agar medium and incubated at $37^{\circ} \mathrm{C}$ for 24 hours to ensure that the absence of bacterial growth and for a week to ensure the absence the fungi growth.

\section{Classification of blue-green alga $O$. pseudogeminata}

The blue green alga was classified based on morphological identification $(18,19)$.

\section{Extraction of Microcystins}

Luukkainen et al., (20) method was used to extract hepatotoxins (MCs), taking 50mg from the algal biomass and then mixed with the water solution (MBW): Water: Methanol: n-Butanol in proportion $15: 1: 4 \mathrm{ml}$ respectively in $100 \mathrm{~mL}$ conical flasks with tin and cotton foil blocked to prevent evaporation. The samples were then mixed thoroughly using a magnetic stirrer for one hour. The supernatant was collected by centrifugation at $3000 \mathrm{rpm}$ for $10 \mathrm{~min}$. The process was repeated three times; the total supernatant was collected and concentrated to $5 \mathrm{~mL}$ using hot dry air.

\section{Purification of Microcystins}

The method of Namikoshi et al, (21) was used to purify toxins using column chromatography. After some modification, a glass column of $15 \times 2$ $\mathrm{cm}$ was used to purify MCs filled with silica gel with mesh size 200-100 $\mu$. The extracted and concentrated sample in the previous paragraph was loaded in the separation column and was washed with three solvents: $20 \mathrm{ml}$ of ion-free distilled water, $20 \%$ methanol, and $80 \%$ methanol respectively at flow rate $3 \mathrm{ml} / \mathrm{min}$. The last eluent was concentrated and preserved at a temperature of $\left(-8 C^{0}\right)$ in refrigerator until analyzed using Enzyme linked Immuno-Sorbent Assay (ELISA) technique. Abraxis Company (United States) kit was used and method was adopted (22).

Effect of purified microcystins from alga $O$. pseudogeminata on total root and shoot (vegetative) of tomato plant.

The experiment of cultivating tomato plant and irrigated with algal toxins was done in laboratory / Faculty of Education-University of Basra/Iraq for the during spring season 2017 in controlled laboratory conditions. The seeds of the tomato Lycopersicon esculentum CV (Cultivar) were prepared by Hoda Dutch origin from Dubban Agricultural Company in Baghdad, Iraq, which is resistant to harsh conditions. Three concentrations of purified microcystins from alga $O$. pseudogeminata represented by $0.5,3.0$ and 6.0 $\mu \mathrm{g} / \mathrm{L}$ were used to irrigate the tomato plant periodically and for irrigation every three days depending on the field capacity and for 24 days 
after reaching the plant two months of age over the control group irrigated with distal water.

The seeds were sown in cork plates containing 99 hole with diameter $4 \mathrm{~cm}$ and height of $6 \mathrm{~cm}$ filled with peat moss and planted one seed in each hole on 10/3/2017 and placed on a stand inside the laboratory. The seedling was sown with $12.8 \mathrm{~cm}$ diameter and $11 \mathrm{~cm}$ high. They contained sandy clay soil with 1: 1 peat moss (500 $\mathrm{g}$ of mix). The seedlings were sprayed as foliage application by urea at a concentration of $0.5 \mathrm{~g} / \mathrm{L}$ after 16 and 23 days from planting and to protect it from a disease of Damping off were sprayed with Ridomil Gold at a concentration of $0.5 \mathrm{ml} / \mathrm{L}$ at 10 days from planting and was protected from the worms by spraying with a $0.4 \mathrm{~mL} / \mathrm{L}$ at 19 days of planting. The experiment included four groups, each group containing three replicates (each containing three plants). Three groups were treated with three purified microcystins concentrations mentioned above in addition to the control group (which is not treated with purified microcystins).

\section{Statistical analysis}

Statistical package for social sciences (Version-22) was used to analyze data using OneWay analysis of variance (ANOVA) at the probability level $(\mathrm{p} \leq 0.05)$. The value of revised least significant differences (R.L.S.D.) was applied to compare the differences means according to ALRawy and Khalaf-Allah (23).

\section{Results:}

Description and classification of the blue-green alga $O$. pseudogeminata

This blue-green alga inhabits wet soils, it was long threads (tricomes) wrapped irregularly, tangled and immobile, thread cells have clear boundaries and the threads appear green under light microscope. The algal cells contain visible gas vacuoles, which are regularly spread in the cytoplasm of the cell, which appear as black dots on the boundary between the cells forming the dermal thread and the thread ends with an around shape. The length of cells range between 2.3-3 $\mu \mathrm{m}$ and the width 1.1-1.4 $\mu \mathrm{m}$ as shown in Fig.1.

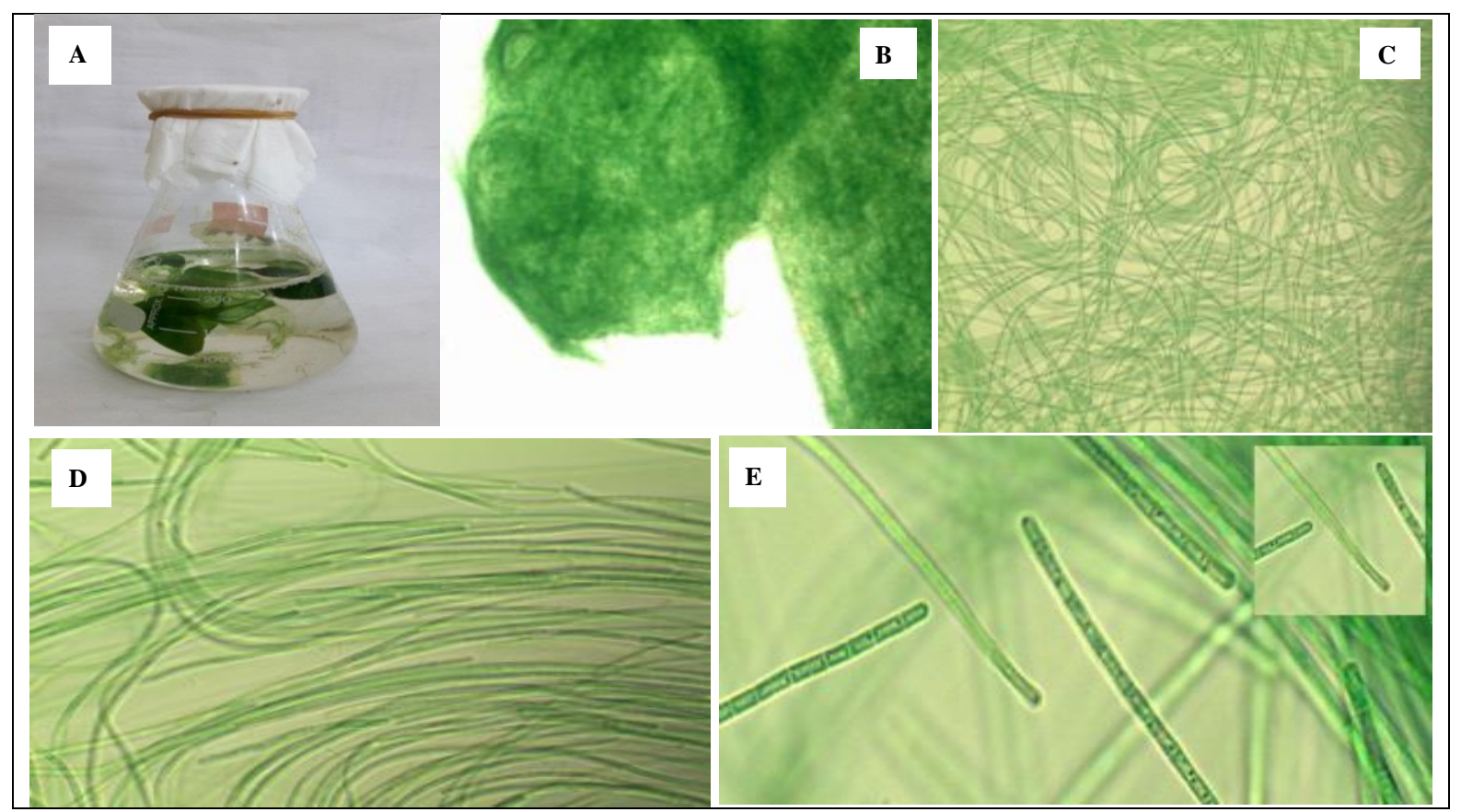

Figure 1. (A): The pure liquid culture of alga $O$. pseudogeminata after a period of 25 days of cultivation. (B): $4 \mathrm{X},(\mathrm{C}): 10 \mathrm{X},(\mathrm{D}): 40 \mathrm{X}$ and $(\mathrm{E}): \mathbf{1 0 0 X}$

\section{Growth curve}

The initial phase of the alga $O$. pseudogeminata took three days, followed by the 27-day exponential phase, with a steady speed in growth, which continued until the 30th day. Stationary phase, which continued until the $47^{\text {th }}$ day, Decline phase on the forty-eighth day to the sixtieth day and therefore the alga was harvested in the middle of the stability phase between the thirtythird day and the $40^{\text {th }}$ day. Estimation of growth rate $(\mathrm{K}=0.144)$ and the generation time of $(\mathrm{G}=2.09)$ of days of the investigated alga as recorded in Table-1.

Table 1. Growth curve periods (days) of blue-green alga $O$. pseudogeminata for 60 days of cultivation in BG-11 liquid medium.

\begin{tabular}{lccccc}
\hline Algal species & Lag phase & Exponential phase & Stationary phase & Harvested days & Growth constant \\
\hline O.pseudogeminata & $\mathbf{3}$ & $\mathbf{2 7}$ & $\mathbf{1 7}$ & $\mathbf{3 3 - 4 0}$ & $\mathbf{0 . 1 4 4}$ \\
\hline
\end{tabular}




\section{Qualitative and quantitative assessment of Microcystins in alga}

The qualitative and quantitative assessment of hepatotoxicity of microcystins (MCs) after purification was determined using enzyme-linked immunosorbent assay (ELISA) technique. The results showed that $O$. pseudogeminata was able to produce MCs with a concentration of $1.47 \mu \mathrm{g} / \mathrm{L}$ for $50 \mathrm{mg}$ algal dry weight.

The ability of tomato plant (L. esculentum) to bio-accumulate purified microcystins

The results shown in Fig.3 showed significant differences at $(\mathrm{P} \leq 0.05)$ between tomato plant groups treated with different concentrations of MCs purified from $O$. pseudogeminata for 24 days of exposure to these toxins (irrigation periods). The highest concentration was found in the plants of the treated group with $6.0 \mu \mathrm{g} / \mathrm{L}$ with a concentration rate of $12.278 \mu \mathrm{g} / \mathrm{L}$ in the whole plant body with a daily accumulation rate of $0.511 \mu \mathrm{g} / \mathrm{L}$ and the highest concentration in the plants group treated with $6.0 \mu \mathrm{g} / \mathrm{L}$ was found in the roots at an average of $4.818 \mu \mathrm{g} / \mathrm{L}$ followed in descending order by stems $4.091 \mu \mathrm{g} / \mathrm{L}$ and leaves $3.369 \mu \mathrm{g} / \mathrm{L}$. While, the mean concentration of toxins in the entire plant body in plants group treated with $3.0 \mu \mathrm{g} / \mathrm{L}$ was $3.856 \mu \mathrm{g} / \mathrm{L}$ with a daily accumulation rate of 0.16 $\mu \mathrm{g} / \mathrm{L}$ per day with concentrations of $1.717 \mu \mathrm{g} / \mathrm{L}$ in the root and $1.499 \mu \mathrm{g} / \mathrm{L}$ in the stem and $0.640 \mu \mathrm{g} / \mathrm{L}$ in leaves. The lowest concentration of accumulated microcystins was found in the plant group treated with $0.5 \mu \mathrm{g} / \mathrm{L}$ and with a daily bioaccumulation rate of $0.069 \mu \mathrm{g} / \mathrm{L}$ per day. The highest concentration of toxins was $0.687 \mu \mathrm{g} / \mathrm{L}$ in the roots followed by the concentration of $0.588 \mu \mathrm{g}$ $/ \mathrm{L}$ in stems then in the leaves at a concentration of $0.425 \mu \mathrm{g} / \mathrm{L}$ (thus the total concentration of 1.670 $\mu \mathrm{g} / \mathrm{L}$ in the whole plant body) as shown in Fig.4, 5.

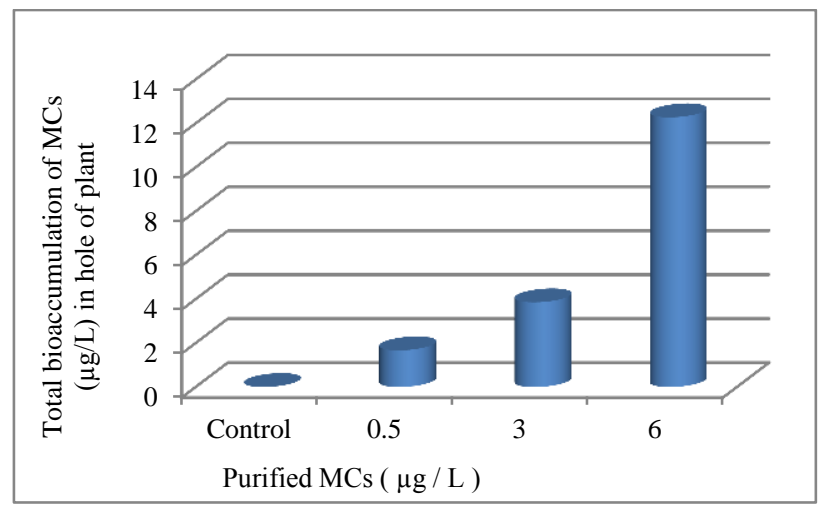

Figure 3. Purified MCs bioaccumulation in plant body $(\mu \mathrm{g} / \mathrm{L})$ for each $250 \mathrm{~g}$ D.W).

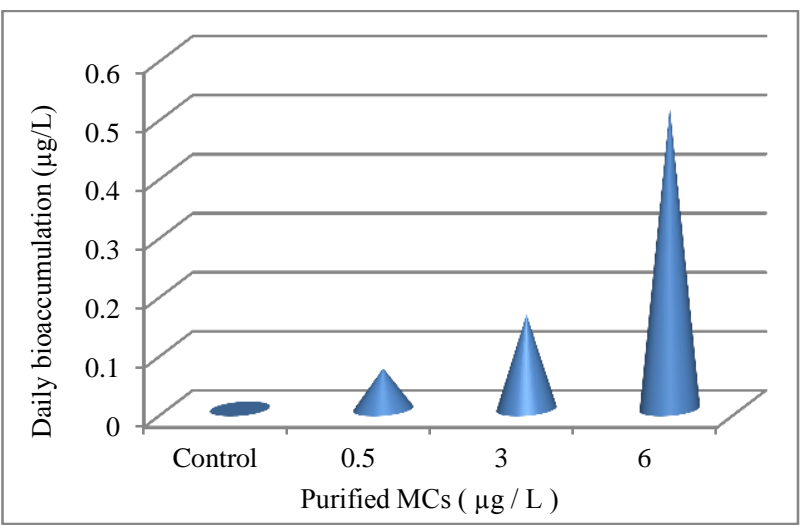

Figure 4. Daily bioaccumulation of purified toxins (MCs) in whole plant body $(\mu \mathrm{g} / \mathrm{L})$.

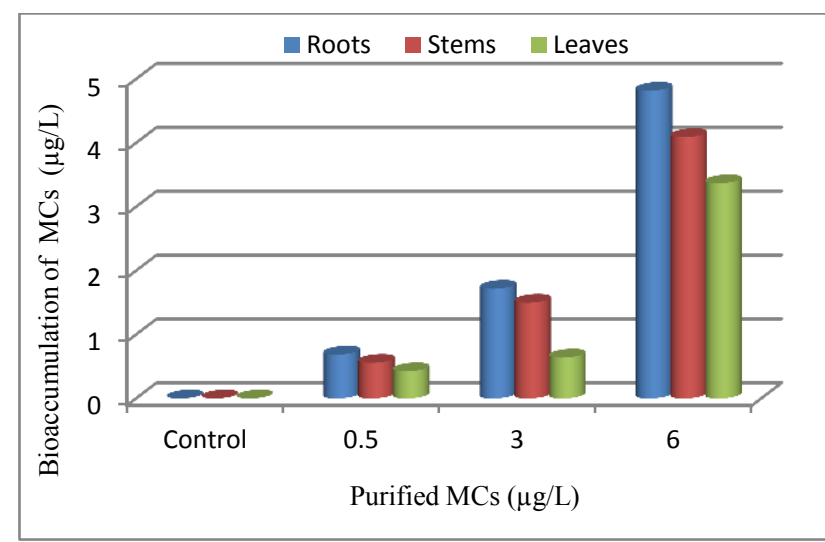

Figure 5. Purified MCs bioaccumulation in different plant body stem roots and leaves $(\mu \mathrm{g} / \mathrm{L})$ for each $250 \mathrm{~g} \mathrm{DW}$

\section{Effect of purified MCs on mean length of plant stems, roots and surface area of leaves.}

The obtained results showed a significant decrease $(p \leq 0.05)$ in stems length of plant, especially when irrigated by the concentration of 6 $\mu \mathrm{g} / \mathrm{L}$ which reached to $20.2 \mu \mathrm{g} / \mathrm{L}$ compared with control group $28.3 \mu \mathrm{g} / \mathrm{L}$, while there were no significant differences between the rests of transactions Fig.6 and7. Also the root length decreased significantly $(\mathrm{p} \leq 0.05)$ especially under dose 3 and $6 \mu \mathrm{g} / \mathrm{L}$ which reached to 5.733 and $6.133 \mu \mathrm{g} / \mathrm{L}$ respectively, but the lowest concentration $0.5 \mu \mathrm{g} / \mathrm{L}$ did not show a significant difference with the control group (Fig.8).The surface area to tomato leaves decreased only under concentration $6 \mu \mathrm{g} / \mathrm{L}$ reaching to 23.3 decimeter $^{2}$ compared to the other concentrations which showed non-significant differences with control plants Fig.9. 


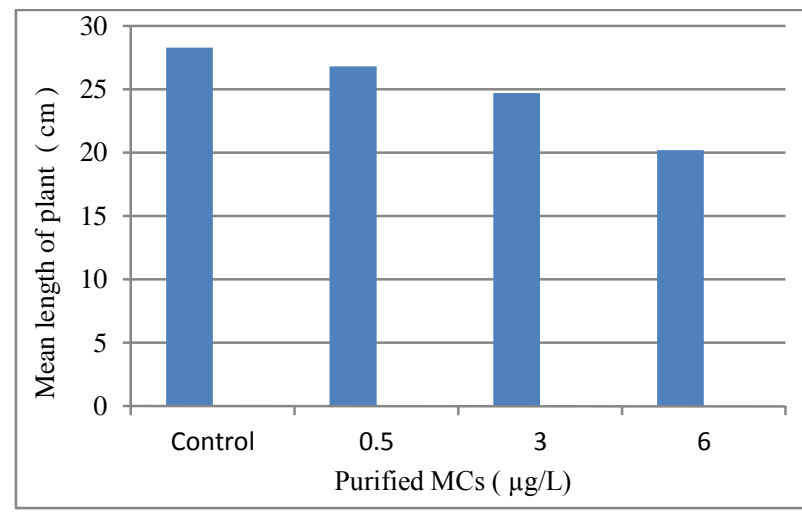

Figure 6. Plant stems length under different conc. of purified MCs.

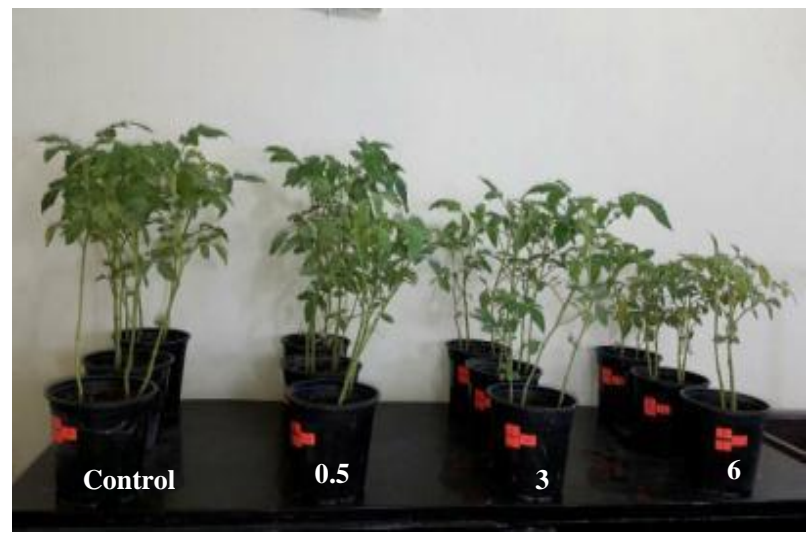

Figure 7. Toxic effects of Purified MCs on length of tomato plant under different conc. of toxins.

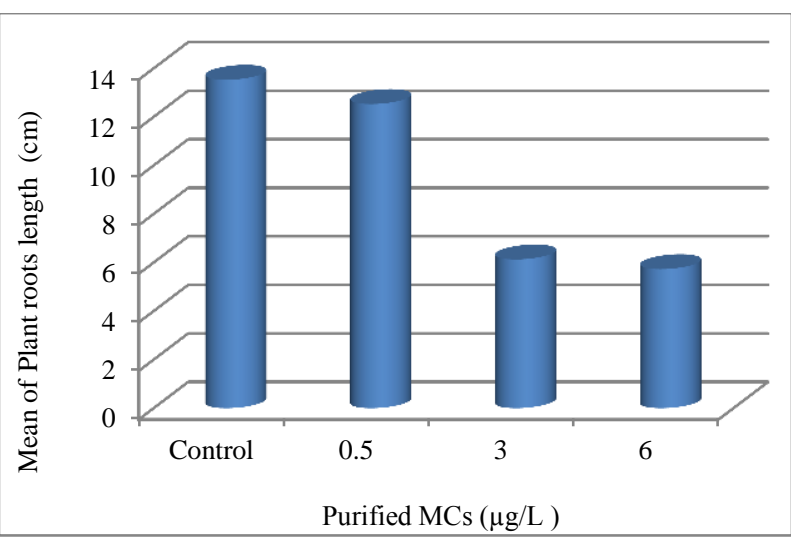

Figure 8. Plant root length under different conc. of purified MCs.

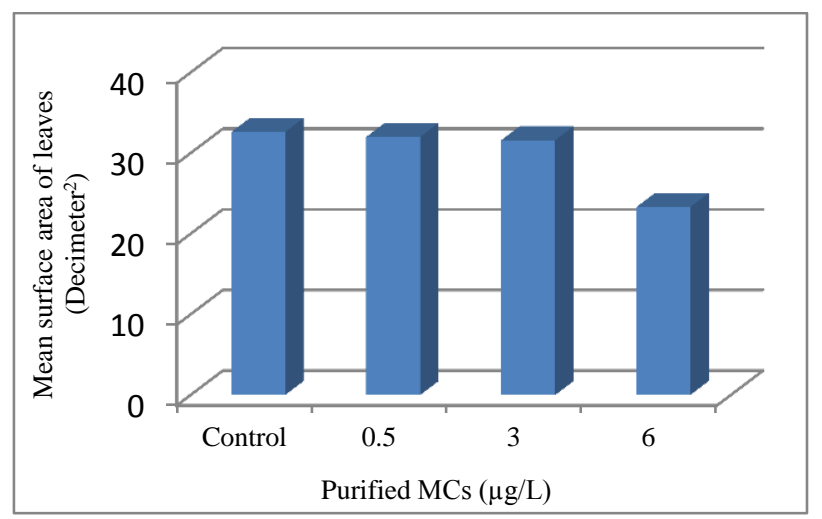

Figure 9. Surface area of plant leaves under different conc. of purified MCs.
Toxic effects of purified MCS on total chlorophyll and carbohydrate concentrations in plant leaves

Results showed significant differences $(p \leq 0.05)$ in total chlorophyll concentration with increasing purified toxin concentration especially under $6.0 \mu \mathrm{g} / \mathrm{L}$ concentrations which reached 0.138 $\mathrm{mg} / 100 \mathrm{~g}$ ww. followed by other concentrations and compared with control group which reached to $0.283 \mathrm{mg} / 100 \mathrm{~g}$ ww and the leaves appeared pale green in color with increasing toxin concentrations. On the other hand, the increase in purified toxins led to a significant decrease in carbohydrate concentration especially under 6.0 and $3.0 \mu \mathrm{g} / \mathrm{L}$ purified toxins which reached to $33.64 \mathrm{mg} / \mathrm{g} \mathrm{dw}$ and $38.73 \mathrm{mg} / \mathrm{g} \mathrm{dw}$ respectively compared with that produce under toxin concentration $0.5 \mu \mathrm{g} / \mathrm{L}$ and control group which reached to 45.94 and 55.95 $\mathrm{mg} / \mathrm{g}$ dw respectively is illustrated in Fig.10,11 and 12 .

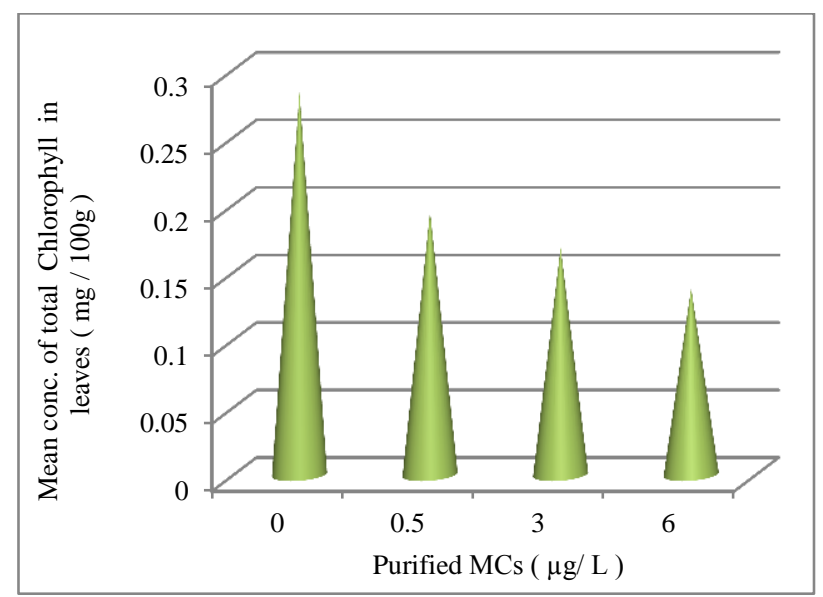

Figure 10. Total chlorophyll conc. in leave of plant under different conc. of purified MCs.

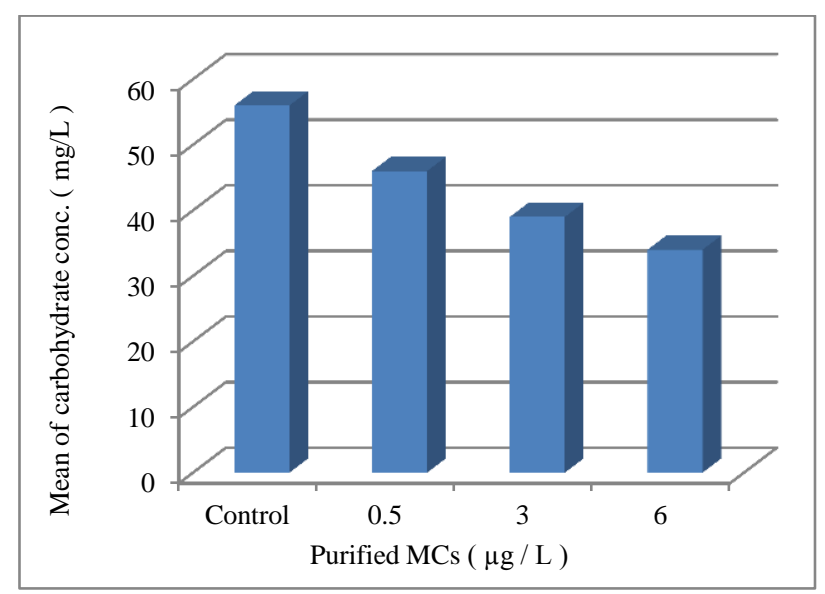

Figure 11. Carbohydrate conc. in leave of plant under different conc. of purified MCs. 

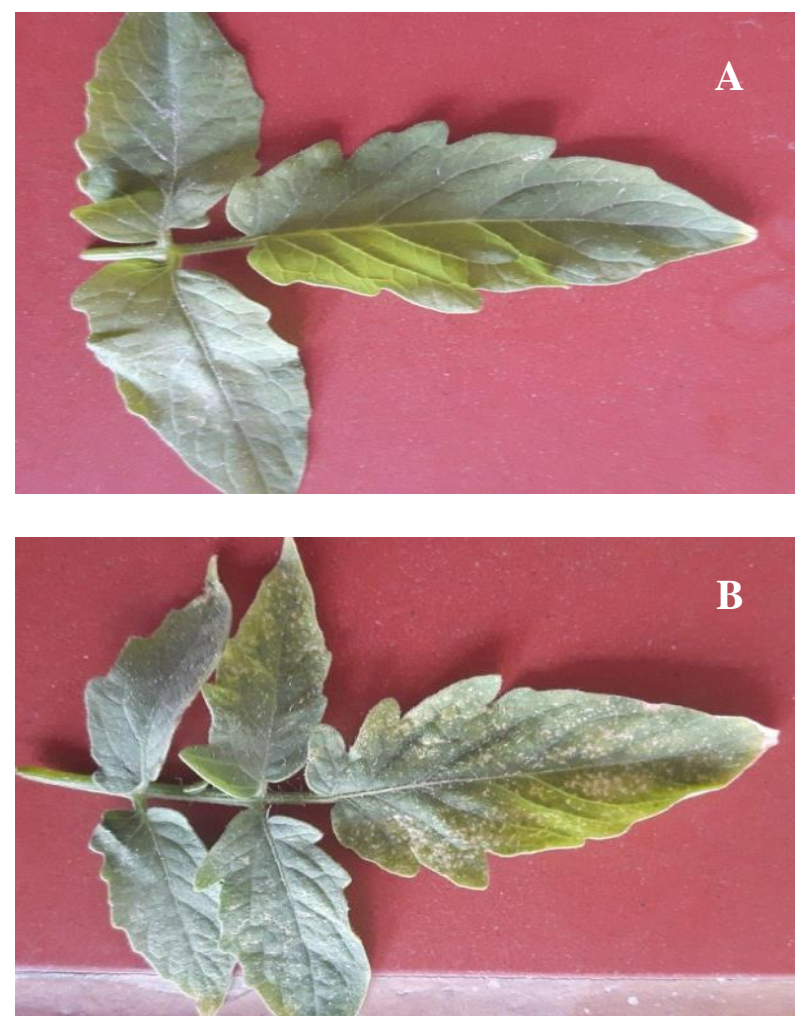

Figure 12. Toxic effects of purified MCs on color of leaves. (A): Control group, (B): Treatment group with $6 \mu \mathrm{g} / \mathrm{L}$ of purified toxins.

\section{Discussion:}

Several previous studies have been concerned with blue green algae and their toxins production in the aquatic environments and purified toxins (MCS) on mice, fish and snails $(24,25,26$, 27, 28, and 29). However, the current study is concerned with the toxicity of algae inhabiting the wet land (Soil algae) and its ability to produce hepatotoxins, especially the microcystins and their effects on one of the economically important plants. Results showed the ability of soil alga $O$. pseudogeminata to produced high concentration of microcystins reached to $1.47 \mu \mathrm{g} / \mathrm{L}$ for $50 \mathrm{mg}$ of algal dry weight, equal to $870 \mu \mathrm{g} / \mathrm{L}$ for $1 \mathrm{~g}(1000$ $\mathrm{mg}$ ) of algal dry weight, so this result is considered the first attempt to the isolation, purification of blue green algae from Iraq soil and study their ability to produce microcystins, This algae showed producing high amount to microcystins compared with other species isolated from sewage and fresh water. The growth curve of this alga in BG-11 liquid medium showed less growth constant from the same species ,but isolated from water environment ( fresh water) (Shutt Al-Arab river southern of Iraq) and cultivation in Chu-10 liquid medium as reported by Aubaed (30).

In this study, the bioaccumulation of purified MCs from soil blue-green alga $O$. pseudogeminata was studied to identify its impact on different parts of the tomato plant (L. esculentum) represent in roots, leaves and stems after irrigation for 24 days with water containing different concentrations of these purified toxins. This study is different from most of the other studies where it neglect using high toxin concentrations to using concentrations that near to the natural environment concentration in water bodies represented by concentration $0.5 \mu \mathrm{g} /$ $\mathrm{L}$, which is considered to be less than the acceptable concentrations $(1 \mu \mathrm{g} / \mathrm{L})$ according to the WHO classification (31).In addition to apply high concentration 3.0 and $6.0 \mu \mathrm{g} / \mathrm{L}$.

Concerning the previous studies, which indicated that blue-green algae toxins, especially MCs, can be bio-accumulated in various crops when irrigated with water contaminated with blue-green algae or toxins $(32,33,34,35$ and 36). The main mechanism of hepatotoxicity in both animals and plants is inhibition of serine / threonine proteins phosphatases 1 and 2A (PP; PP1 and PP2A) by associating with covalent bonds $(37,38)$. Although the target molecules look the same enzymes in both animals and plants, the plant's absorption mechanism for MCs is not yet explored and specific vectors have not yet been identified in the plants. However, these carriers may be similar to peptides and amino acids in plants (39). Since microcystins are peptide compounds, it is probable to suggest that peptides may be involved in the transfer of microcystins in plants (40). Finding appeared that the plants treated with high dose of purified toxin showed highly accumulation of toxins in different plant tissues when compared with the control group. These results are consistent with the study of Hereman and Bittencourt-Oliveira (41) they found that the amount of concentrations measured in plants depends on the amount of concentrations in the water used for irrigation.

The significant differences in the accumulation of MCs in different parts of the tomato plant with increasing purified toxins in irrigation, specifically in the root were recorded in this study. Microcystins was accumulated in the body of the plant with increased concentrations treated and the highest concentration of toxins was found in the roots of plants treated with all concentrations compared to the stems and leaves. In spite of the fact that the root of the tomato plant is not the part used for nutrition by the human, but in many plants where the root is the edible part increase the risk of toxin accumulated in the plant roots exposed to irrigation with container water on blue-green algae or their toxins, especially the daily exposure allowed for microcystins developed by WHO (31) Is $0.04 \mu \mathrm{g} / \mathrm{kg} \mathrm{B.W} /$ day. These results were in agreement with the study of GutiérrezPraena et. al., (33). Their found that the highest concentration of microcystin in root after irrigating 
the tomato plant every three days with $500 \mathrm{ml}$ of water containing $100 \mu \mathrm{g} / \mathrm{L}$ of crude microcystins for two weeks. Studies on Broccoli and Mustard Sinapis alba showed that microcystins were found only in the roots of these plants with concentrations ranging from 0.9-2.4 $\mu \mathrm{g} / \mathrm{kg}$ for broccoli and 2.5$6.6 \mu \mathrm{g} / \mathrm{kg}$ of mustard weight after exposure to microcystins concentration between 1 and $10 \mu \mathrm{g} / \mathrm{L}$ for 20 and 19 days respectively (42). The study of Machado et al., (36) also reported that the accumulation of hepatotoxin type MC-LR in carrot type Daucus carota was $5 \mu \mathrm{g} / \mathrm{kg}$ wet weight when exposed to hepatotoxin type MC-LR at 10 and 50 $\mu \mathrm{g} / \mathrm{L}$ for 32 days after reaching the plant to one month of age. Since the root is the edible part of the carrot plant, there are fears that toxins can spread through the food chain and threaten human health.

Several significant changes in the vegetative growth indicators of tomato plant when exposed to the purified toxins (MCs), denoted by decreasing the length of the stems, roots and surface area of the leaves. The results are consistent with the study of Dao et al., (43), despite the use of high concentrations of microcystins reach to 20 and 200 $\mu \mathrm{g} / \mathrm{L}$ affected significantly the plant seedlings of the type Brassica rapa and turnip type B. narinosa and watercress plant type Nasturtium officinale which led to a decrease in the length of the stem and root .The study of Pereira et al., (44) also showed inhibited root growth in lettuce Lactuca sativa when exposed to the extract of hepatotoxins (MCs) with concentrations of 5.9 to $56.4 \mu \mathrm{g} / \mathrm{L}$. These results were also parallel with the study of Pflugma Cher et al (45) who recorded very clear decrease in the surface of the leaves of spinach (Spinacia oleracea) leaf area type when exposed to microcystins (45). In addition to the morphological changes, the pale green color (Chlorosis) of leaves of the tomato plant with increasing in MCs, caused decrease in chlorophyll concentration and carbohydrates reserves ,this results may be due to or associated with disorders in the metabolism of plants exposed to such toxins, Such alteration of metabolism may be as inhibition of photosynthesis, reduction of total chlorophyll content and the difference of chlorophyll concentrations in the tissue of tomato leaves was reversely proportional with the concentration of exposed microcystins $(46,47)$.

\section{Conclusion:}

We concluded from the present findings that blue-green algae specifically the alga $O$. pseudogeminata may affect directly the growth of plants. The irrigation of agricultural crops by water contaminated with blue-green algae or their toxins does not only raise economic and environmental problems, but also health problems for consumers, especially field crops, due to the accumulation of these toxins in plant tissues and their transmission through the food chain, Even though the concentrations of toxins are very low.

\section{Conflicts of Interest: None.}

\section{References:}

1. Bacher L, Manassaram-Baptiste D, Leprell R ,Balton B. Cyanobacteria and green algae blooms ; a review of health and environmental data from the harmful algal bloom related illness surveillance system (HABISS),Toxins,2015; 7(4): 1048-1064. Doi: 10.3390/toxins7041048.

2. Addico GND, Lawton L, Edward C. Hepatotoxic microcystins in two drinking water reservoirs in central region of Ghana. Toxicol. and Forensic Medicine, 2017; 2910:1-11.

3. Al-sultan EY, Aubaeed MAAI. Isolation of four new species of blue-green algae and diagnosis, purification, cultivation from the Shatt Al-Arab waters in Basra, southern of Iraq, and evaluation their ability to produce neurotoxins (Anatoxin-a) and hepatotoxin (Microcystins). J. of Basra Res. (Sciences). , 2017; 43(b):125-14.

4. AL-sultan EY, Aubaeed MA. Extraction and purification of neurotoxin 9Anatoxin-a) from blue green alga Pseudoanabaena limnetica and indicating its histopathological effects on the brain of male laboratory mice (Mus Musculus L.),J.of Biology Agriculture and Healthcare ,2017;7(18):77-87.

5. EPA,Financial incentives to address harmful algal blooms ,Fast Sheet ,Ohio Environmental protection Agency ,2014;1-2. Available in: http://epa.ohio.gov/Portals/47/media/HABfundFSAug 14.pdf.

6. EPA, Cyanobacteria and drinking water: Guidance for public water systems .New Hampshire department of Environmental Services, 2016; 4-15. Available from: www.des.nh.gov/organization/commissioner/ pip/factsheets/dwgb/documents/dwgb-4-15.pdf.

7. Corbel S, Mougin C, Bouaïcha, N. Cyanobacterial toxins: modes of actions, fate in aquatic and soil ecosystems, phytotoxicity and bioaccumulation in agricultural crops. Chemosphere, 2014; 96, 1-15. https://doi.org/10.1016/j.chemosphere.2013.07.056.

8. Sukenik A, Salmso N. Global Expansion of toxic and non-toxic cyanobacteria: effect on ecosystem functioning .Biodivers Conserv, 2015; 24:889-908.

9. Barrington DG, Ghadouani A, Lvion GV. Cyanobacterial and microcystins dynamics following the application of hydrogen peroxide to waste stabilization ponds .Hydrol.Earth. Syst. Sci., 2013; 17:2097-2105.

10. Shao J, Li R, Lepo JE, Gu JD. Potential for control of harmful cyanobacterial blooms using biologically derived substances; problems and prospects. Journal of Environmental management, 2013; 125:149-155. Doi.org/10.1016/j.jenvman.3013.04.001.

11. Drobac D, Tokodi N, Simennovic J, Baltic V, Stanic D, Svicev Z. Human exposure to cyanotoxins and 
their effects on health . Arh. Hig Rada. Toksikol, 2013; 64:305-316. Doi: 10.2478/10004-1254-642013-2320.

12. Schmidt JR, Wilhem SW, Boyer GL. The fate of microcystins in the environment and challenges for monitoring. Toxicon, 2014; 6:33543390.Doi:103390/toxins6123354.

13. Praena DG, Camps A, Azevedo J, Neves J. Freitas M, Guillen RG, et al., . Exposure of Lycopersicon esculentum to microcystins-LR: Effects in the leaf proteome and toxin translocation from water to leaves and fruits, Toxins, 2014; 6:1837-1837. Doi: 10.3390/toxins6061837.

14. Corbel S, Bouaïcha N, Mougin C. Dynamics of the toxic cyanobacterial microcystin-leucine-arginine peptide in agricultural soil. Environ. Chem., Lett,2014; 1-7. DOI 10.1007/s10311-014-0482-2.

15. Bouaich N, Corbe S. Cyanobacterial toxins emerging contaminants in soil : A review of sources, fate and impact on ecosystems, Plants and animals and human Health [ Internet ]: NTECH,2016;21p. Available from http://www.interchopen .com/books/ soil/.login /URL=http: //dx.doi.org/10.5772/64940.

16. Stein JR. Handbook of phycological method .Cambridge University press .Cambridge. , 1975; pp 445.

17. Weidman VE, Walne PR, Tainor, FR. A new technique for obtaining axenic cultures of algae. Can. J. Bot., 1984; 42: 958 -959.

18. Desikachary TU. Cyanophyta. Indian council of agricultural search, New Delhi, 1959; 73:517-44.

19. Prescott GW. Algae of the western great lake area. 6th ed., William C. Brown Co. Publishers. Dubuque, Towa, 1975; PP 977.

20. Luukkainen R, Sivonen K, Namikoshi M, Farding M, Rinehart KL, Niemeta S. Isolation and identification of eight Microcystins from thirteen Oscillatoria agardhii strains and structure of new Microcystin. Applied and Envir. Microbiol. , 1993; $2204-2209$.

21. Namikoshi M, Choi BW, Sun F, Rinehart, KL. Chemical characterization and toxicity of Dihydro Derivatives of Nodularin and Microcystin - LR potent cyanobacterial cyclic peptide hepatotoxins. Chem. Res. Toxicol., 1993; 92:151 158.

22. Fischer WJ, Garthwaite I, Miles CO, Ross KM, Aggen JB, Chamberlin AR, Towers NA, Dietrich DR. Congener-Independent Immunoassay for Microcystins and Nodularins. J.of Environ. Sci. Technol., 2001; 35, 2001, 4849-4858.

23. Al-Rawy KM, Khalaf Allah AM. Evaluation and analysis of agriculture experiments. Dar Al Kut Books for Printing and Publishing, Faculty of Agriculture and Forestry, University of Mosul., 1980; pp. 189.

24. Al-Sultan EY. The Isolation, the purification and the identification of Hepatotoxin Microcystin-LR from two cyanobacterial species and studying biological activity on some aquatic organisms Journal of Basra Researches ((Sciences))., 2011; 37(10):39-57.

25. Al-Sultan EY. Isolation, Purification and Identification of Blue-green Alga Hapalosiphon auras and Evaluation of its Histopathological Effects on Fresh Water Snail Lymnaea auricularia. J. of Applied sci, 2017; 17(2) 61-71. http://dx.doi.org/10.3923/jas.2017.61.71.

26. AL-Sultan EY, Mahmood JY. Ecological study of sedimentation basins for two purification drinking water stations petrochemical and AL-Ribatt in Basra governorate /Southern of Iraq and determination cyanotoxins (microcystins),J.of AL-qadisiya for pure sciences ,2016;21(3);52-70.

27. Carmichael ww, Boyer GL. Health impacts from cyanobacteria harmful algae blooms: Implications for the North American Great Lakes. J.of Harmful Algae, 2016; 54,194-212.

28. AL-Sultan EY, Abbas SS.Toxic effects of sub lethal dose of algal toxins (Microcystins-LR) on male laboratory mice (Mus Musculus L.) ,Int.J.of Biosci.,2017;11(5):192-

203.https://doi.org/0.12692/ijb/11.5.192-203.

29. Majeed MA, AL-Sultan EY, Abass AK.Toxic effects of low concentration of cyanotoxins (MicrocystinLR) on mice and study of protective efficacy of the antioxidants vitamins $(\mathrm{C} \& \mathrm{E})$ and Capparis spinosa $\mathrm{L}$. root extract. J. of Nat. Sci. Res., 2016; 6(2):34-42.

30. Aubaeed MAA. Capability of some blue-green algae isolated from some water bodies in Basra governorate /southern of Iraq to production of toxins, Thesis, College of Education for Pure Sciences, Basra University , 2017 ; PP122.

31. WHO, Toxic cyanobacteria in water: A guide to their public health consequences, monitoring and management, 1999.

32. Hereman TC, do C. Bittencourt-Oliveira M, "Bioaccumulation of Microcystins in Lettuce," Journal of Phycology, 2012; 48( 6)1535-1537

33. Gutierrez-Praena D, Campos A, Azevedo J, Neves J, Freitas M, Guzman-Guillen R, et al., . Exposure of Lycopersicon esculentum to microcystin-LR: Effects in the leaf proteome and toxin translocation from water to leaves and fruits. Toxins. , 2014; 6(6): 18371854. Doi: 10.3390/ toxins6061837.

34. Bittencourt-Oliveira MC, Cordeiro-Araújo MK, Chia MA, Arruda-Neto JDT, Oliveira T, Santos F. Lettuce irrigated with contaminated water: photosynthetic effects, antioxidative response and bioaccumulation of microcystin congeners. Ecotoxicol. Environ. Saf. , 2016; 128, 83-90.

35. Cordeiro-Araújo MK, Chia MA, Arruda-Neto JDT, Tornisielo VL, Vilca FZ, Bittencourt-Oliveira, M.C. Microcystin-LR bioaccumulation and depuration kinetics in lettuce and arugula: human health risk assessment. Sci. Total Environ. , 2016; 566-567, 1379-1386. https://doi.org/10.1016/j.scitotenv.2016.05.204.

36. Machado J, Azevedo J, Freitas M, Pinto E, Almeida A, Vasconcelos V, , Campos A. Analysis of the use of microcystin-contaminated water in the growth and nutritional quality of the root-vegetable, Daucus carota. Environ. Sci. Pollut. Res. Int., 2017; 24(1): 752-764. Doi: 10.1007/s11356-016-7822-7.

37. MacKintosh C, Beattie KA, Klumpp S, Cohen P, Codd GA. Cyanobacterial microcystin-LR is a potent and specific inhibitor of protein phosphatases 1 and 
2A from both mammals and higher plants. FEBS Lett, 1990; 264:187-192.

38. Dawson RM. The toxicology of microcystins. Toxicon, 1998; 36, 953-962.

39. Tegeder M, Rentsch D. Uptake and partitioning of amino acids and peptides. Mol. Plant, 2010; 3, 9971011.

40. Fischer WL, Altheimer S, Cattoro V, Meier PJ, Dietrich DR, Hagenbuch B. Organic anion transporting polypeptides expressed in in liver and brain mediate uptake of microcystin. Toxicol. Appl. Pharm., 2005; 203(3):275-263. https://doi.org/10.1016/j.taap.2004.08.012.

41. Hereman TC, Bittencourt-Oliveira MC, "Bioaccumulation of Microcystins in Lettuce," Journal of Phycology, 2012; 48 (6): 1535-1537.

42. Järvenpää S, Lundberg-Niinistö C, Spoof L, Sjövall O, Tyystjärvi E, Meriluoto J. Effects of microcystins on broccoli and mustard, and analysis of accumulated toxin by liquid chromatography-mass spectrometry., Toxicon, 2007; 49(6): 865-74. https://doi.org/10.1016/j.toxicon.2006.12.008

43. Dao TS, Le TH, Pham TL, Do-Hong LC, Nguyen PD. Influences of Cyanobacterial Toxins Microcystins on the Seedling of Plants, J. Environ. Prot. (Irvine. Calif), 2014; 5 (1): 35-41.
44. Pereira S, Saker ML, Vale M, Vasconcelos VM. Comparison of sensitivity of grasses (Lolium perenne L. and Festuca rubra L.) and lettuce (Lactuca sativa L.) exposed to water contaminated with microcystins. Bull. Environ. Contam. Toxicol. 2009, 83: 81-84. https://doi.org/10.1007/s00128-009-9763-z.

45. Pflugmacher S, Aulhorn M, Grimm B. Influence of a cyanobacterial crude extract containing microcystinLR on the physiology and antioxidative defense systems of different spinach variants. New Phytol. , 2007a; 175 (3): 482-489.

http://dx.doi.org/10.1111/j.1469-8137.2007.02144.x. PMid: 17635223.

46. El Khalloufi F, El Ghazali I, Saqrane S, Oufdou K, Vasconcelos V, Oudra B. Phytotoxic effects of a natural bloom extract containing microcystins on Lycopersicon esculentum. Ecotoxicol. Environ. Saf., 2012;79:199-205.Doi:10.1016/j.ecoenv.2012. 01.002 .

47. El Khalloufi F, Oufdou K, Lahrouni M, Faghire M, Peix A, Ramírez-Bahema M, Vasconcelos V, Oudra B. Physiological and antioxidant responses of Medicago sativa-rhizobia symbiosis to cyanobacterial toxins (Microcystins) exposure. Toxicon, 2013; 76:167-177.

https://doi.org/10.1016/j.toxicon.2013.10.003.

\title{
Oscillatoria التاثيرات السامة للمايكروستنينات المنقاة من طحلب التربة الاخضر المزبرق

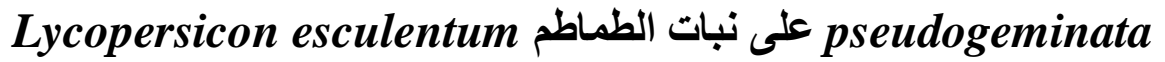

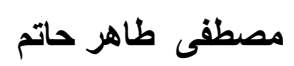

\author{
عماد يوسف عواد سلطان السلطان \\ قسم علوم الحياة، كلية العلوم الصرفة، جامعة البصرة، بصرة، العراق.
}

الخلاصة:

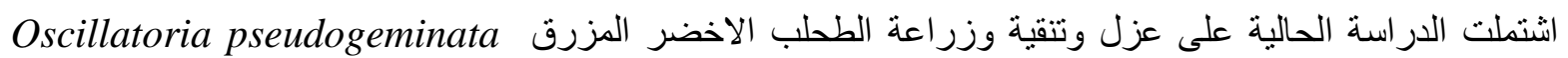

من التربة باستخدام الوسط الزر عي الغذائي السائل G.Schmidle الجيل (G) و الذي بلغ (G الطحلب باستخدام تقنية الامنزاز المناعي المرتبط بالإنزيم

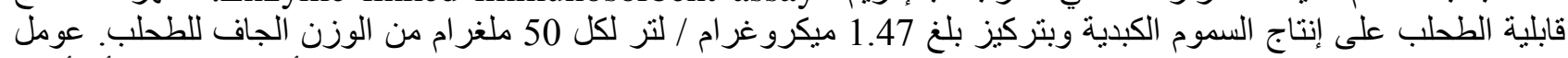

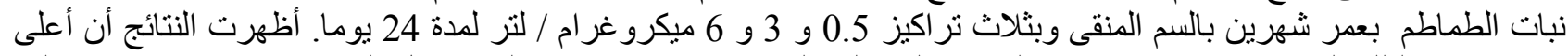

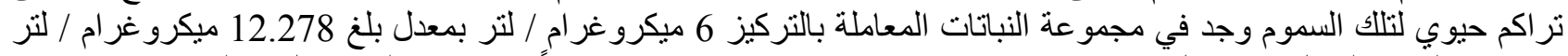

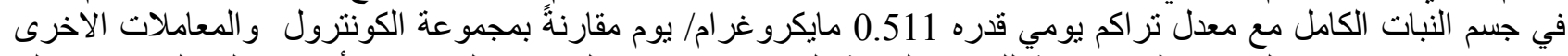

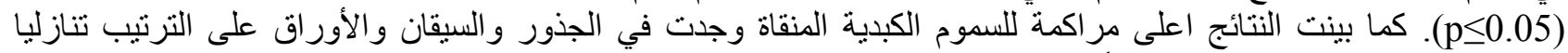

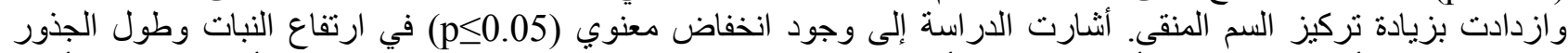

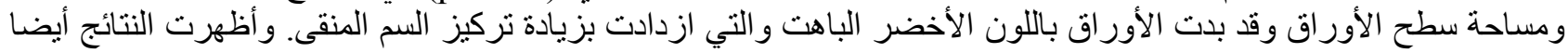

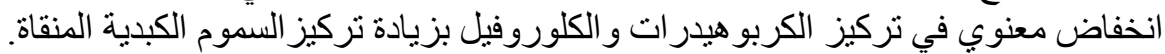

الكلمات المفتاحية: الطحلب الخضر المزرق Oscillatoria pseudogeminata ، المايكروستتينات (السموم الكبدية)، نبات الطماطم Lycopersicon esculentum 